
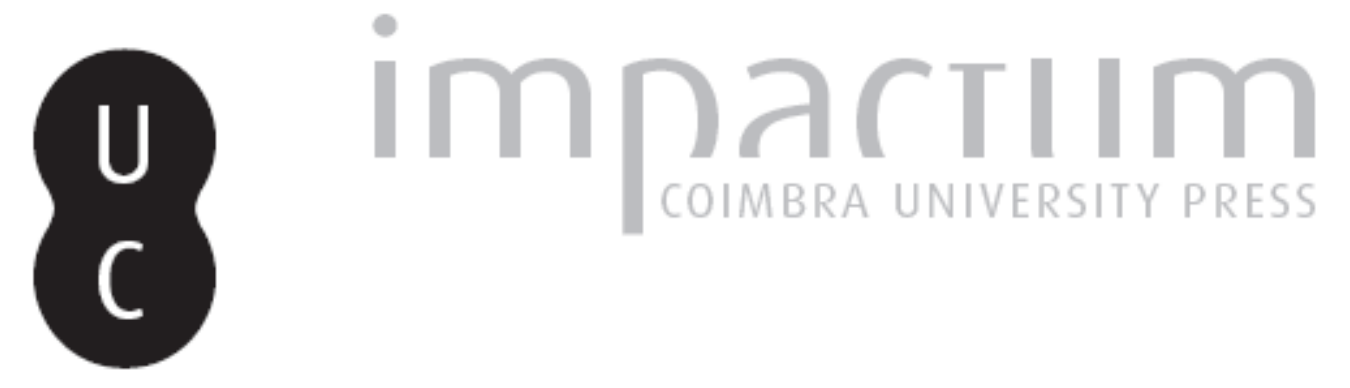

\title{
Folly and dark humor in the life of Demetrius
}

\section{Autor(es): $\quad$ Monaco, Mallory}

Publicado por: International Plutarch Society

URL persistente:

URl:http://hdl.handle.net/10316.2/36363

DOI:

DOI:http://dx.doi.org/10.14195/0258-655X_9_4

Accessed : $\quad$ 26-Apr-2023 15:34:37

A navegação consulta e descarregamento dos títulos inseridos nas Bibliotecas Digitais UC Digitalis, UC Pombalina e UC Impactum, pressupõem a aceitação plena e sem reservas dos Termos e Condições de Uso destas Bibliotecas Digitais, disponíveis em https://digitalis.uc.pt/pt-pt/termos.

Conforme exposto nos referidos Termos e Condições de Uso, o descarregamento de títulos de acesso restrito requer uma licença válida de autorização devendo o utilizador aceder ao(s) documento(s) a partir de um endereço de IP da instituição detentora da supramencionada licença.

Ao utilizador é apenas permitido o descarregamento para uso pessoal, pelo que o emprego do(s) título(s) descarregado(s) para outro fim, designadamente comercial, carece de autorização do respetivo autor ou editor da obra.

Na medida em que todas as obras da UC Digitalis se encontram protegidas pelo Código do Direito de Autor e Direitos Conexos e demais legislação aplicável, toda a cópia, parcial ou total, deste documento, nos casos em que é legalmente admitida, deverá conter ou fazer-se acompanhar por este aviso.

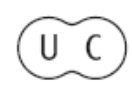


Ploutarchos, n.s.

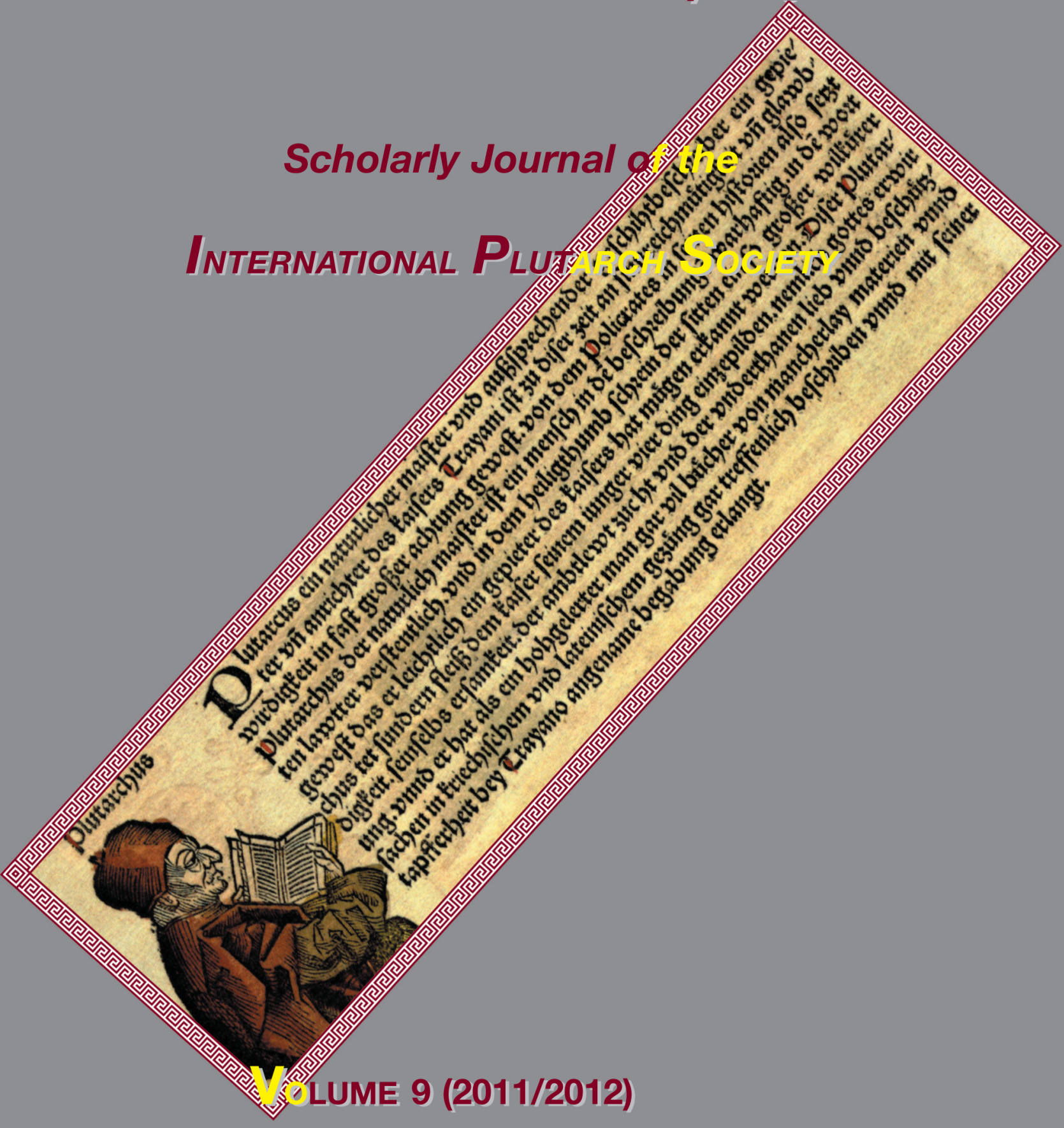

University of Málaga (Spain) Utah State University, Logan, Utah (U.S.A.) 


\title{
Folly and Dark Humor in the Life of Demetrius* by Mallory Monaco Princeton University \\ mallory.monaco@gmail.com
}

\begin{abstract}
Despite Plutarch's claim that his aim is not the amusement of his reader, the Life of Demetrius is full of humor in a variety of forms. Just as the narrative splits into a comic half and a tragic half, Plutarch adapts his use of humor to suit the tone of the narrative context. In the comic half, the humor makes light of Demetrius' vices, while the humor of the tragic half is predominantly gallowshumor, and the characters are reduced to laughing at the death and ruin which Demetrius' reckless ambition has brought to pass. In both halves, Plutarch uses humor not only to entertain his reader, but also as a didactic tool with which he draws attention to Demetrius' moral failings.
\end{abstract}

Key-Words: Plutarch, Life of Demetrius, Dark Humor.

IJ . In the preface to the $D e-$ metrius-Antony pair, Plutarch seeks his readers' indulgence for including a pair or two of rogues, and claims that he is doing so not merely for the sake of variety or amusement, but as lessons of how not to act $(1.5)^{1}$ :

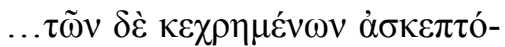

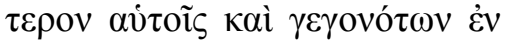

* This paper is a revised version of a presentation first delivered at "Irony and Humour as Imperial Greek Literary Strategies: The Playful Plutarch", 13 July 2011, in Oxford. It also forms the basis for a collaborative article on the use of humor in the Demetrius-Antony pair which M. Beck and I are preparing for publication in the edited volume arising from the Playful Plutarch conference. I would like to thank Eran Almagor, Katerina Oikonomopoulou, and Christopher Pelling for organizing this conference, and special thanks to Eran Almagor, David Kaufman, and Christopher Caterine for their helpful comments.

1 All Greek texts are from the edition of K. ZIEGLER; English translations of the Lives are modified version of B. Perrin, and the Moralia are modified from H. Fowler. 


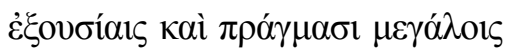

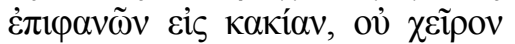

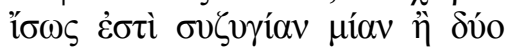

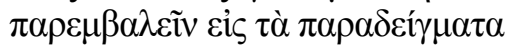

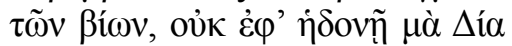

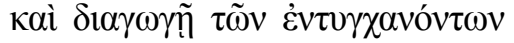

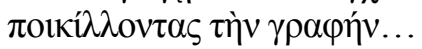

...but when men have led reckless lives, and have become conspicuous for badness, in the exercise of power or in great undertakings, perhaps it is not too wrong for me to introduce a pair or two of them into my Lives, though not, by Zeus, giving variety to my writing for the pleasure and diversion of my readers...

The assertion that he is not including these pairs "by Zeus...for pleasure and diversion" implies, in fact, that there is a very real threat that his readers might find these Lives enjoyable on a low level. In this passage, as Tim Duff has recognized, Plutarch establishes a distinction between an ideal reader - the serious student of moral philosophy and a casual reader, who may be reading Plutarch's works without a specific intellectual goal in mind $^{2}$. A related distinction appears in the Table Talk ${ }^{3}$ : Plutarch argues that if the guests at a dinner-party are mostly philosophers, then weighty philosophical discussions are appropriate to the table; but when the majority of guests are more attentive to musical entertainment than to the voice of the philosopher, the philosopher must tone down his discourses and acquiesce somewhat to the less refined tastes of his fellow guests. The philosopher will not stop philosophizing, but will instead use humor to catch and direct the attention of his less philosophically-minded guests towards the contemplation of higher truths. Plutarch considers this sort of "philosophizing without seeming to do so" a sign of a "true philosopher". Similarly, in the Life of Demetrius Plutarch does not dismiss the pleasurereader from moral training, but instead uses humor to direct the attention of even the casual reader to important moral lessons.

In what follows, I will demonstrate how Plutarch uses humor in the Demetrius, not only as a didactic tool in the manner just described, but also as part of his narrative strategy. The humor in the Life of Demetrius has a variety of forms - one-liners, anecdotes, and witty literary references. Demetrius himself, or the topsy-turvy world he created, is the butt of most of these jokes. Plutarch claims that Demetrius exemplified Plato's saying that great natures exhibit great vices as well as great virtues (1.7); what we find is that these great vices are exactly what gets mocked throughout the Life. Additionally, these humorous moments are integrated into

2 T. DufF, 2004, 279.

3 Plu., Mor. 613E-614A. 
a larger, self-conscious dichotomy between comedy and tragedy which Plutarch uses to structure the narrative. He makes this dichotomy explicit at the halfway mark of the narrative when he says that "Demetrius' fortunes and actions bring the narrative... from the comic stage to the tragic, as it were", a vivid and succinct metaphor to describe the disparate tones of the two halves of the Life (28.1). Both the Demetrius and the Antony are shot through with the imagery of the stage, but until now scholars have limited their research to Plutarch's use of tragedy and tragic imagery. Little attention has been paid to how Plutarch incorporates comedy that is, material from and befitting the comic stage -- into his biographies ${ }^{4}$. My goal is to show how Plutarch adapts his use of humor in the Life of Demetrius to fit within the two spheres of comedy and tragedy and unite the two halves of the narrative. In the comic half, when Demetrius actually seems to display a number of virtues, Plutarch includes several quips and anecdotes making light of Demetrius' vices, adding a subtle but perceptible shadow to his sketch of the young general. The tone of the tragic half of the narrative is more somber than the comic half; yet it is remarkable that humor is not absent from the tragic half, it merely takes a darker color. What was once funny in the comic half is now deadly serious; ruin and death, in turn, become the main source of humor. The overall effect is like a yin-yang, in which light and dark are clearly demarcated but also unified by the presence of the one in the other.

While I will discuss a number of humorous passages from the Life of Demetrius, this essay is intended to be a schematic analysis of how Plutarch uses humor in this Life, not a comprehensive study of every funny passage; unfortunately, some parts have been left on the cutting room floor ${ }^{5}$. To begin, I will discuss two scenes of costume-change, one from the comic half and one from the tragic, to demonstrate how Plutarch modifies a stock-scene to fit the distinct halves of the narrative. Then, I will discuss two prominent figures of the comic half, Demetrius' father Antigonus Monophthalamus, and his mistress Lamia, for illustrations of

4 The paucity of scholarship on the comic in Plutarch was one of the motivating factors for the "Playful Plutarch" conference. For scholarship on tragedy in Plutarch, see PH. DE LACY, "Biography and Tragedy in Plutarch", AJPh, 73 (1952) 159-171; J. Mossman, "Tragedy and Epic in Plutarch's Alexander", JHS, 108 (1988) 83-93; A. ZADOROJNYI, “Tragedy and epic in Plutarch's Crassus", Hermes, 125 (2) (1997) 169-182; T. DufF, "Plato, Tragedy and the Ideal Reader in Plutarch's Demetrios and Antony", Hermes, 132 (2) (2004) 271-291.

5 9.5-6 (Stilpo the Cynic); 11.2-3 (Stratocles the demagogue); 17.2-5 (Aristodemus the fawn); 25.4-6 (Demetrius' pet-names for the Successors), among others. 
how Plutarch uses folly to highlight Demetrius' vices. Finally, we will turn to the dark humor of the tragic half, and the twisted irony of Demetrius' life and death in captivity.

II. There are two times in the Life when Demetrius needed to perform a quick costume-change in order to evade capture during a campaign: first when he was in the midst of liberating cities from Cassander (9.3-4), and then again at the final stage of his war with Pyrrhus (44.6). In the first episode, young Demetrius was caught with his tunic down: during the campaign, Demetrius arranged a rendezvous with the famed beauty Cratesipolis ${ }^{6}$. His enemies fell upon their love-nest, and he hastily tossed on a common cloak and stole away, leaving his tent and its contents as booty for his enemies. This comical escape did not slow Demetrius' liberation campaign, and he soon after captured Megara with ease. The latter episode is much more somber: Demetrius' men, no longer willing to fight to support his luxurious lifestyle, were defecting in droves to Pyrrhus' side. Informed of this, Demetrius en- tered his tent, changed his royal robes for a common cloak, "as if," Plutarch says, "he had been an actor and not a real king," and fled, once again leaving his tent and its contents to be plundered $^{7}$. Unlike before, this time there was no happy ending, and Demetrius entirely lost possession of Macedonia. Plutarch plays on the double meaning of skene as "tent" and "stage" in both of these vignettes, but the two stages he sets are very different: the first is a comic stage, with foolish young lovers, a bit of danger, and everything working out in the end; while the second is a tragic stage, complete with an almost Euripidean king-in-rags who is in the process of losing everything he had once won. Soon after this scene, a Theban quotes lines from the prologue of the Bacchae to mock Demetrius' transformation from a king to a commoner $(45.3)^{8}$. Plutarch calls this reference "not inept", and indeed the Bacchae, with its Dionysiac theme, scenes of costuming, and uncomfortable juxtaposition of comedy and tragedy, is, I believe, just the sort of model Plutarch had in mind when writing the Life of Demetrius.

6 Cratesipolis is a fitting name for a paramour of the Besieger-of-Cities; it seems that Plutarch is having a bit of pun-fun by including her name in this anecdote.

7 This scene, incidentally, is the inspiration for C. Cavafy's poem "O B $\alpha \sigma \imath \lambda \varepsilon v ́ \varsigma \Delta \eta \mu \eta ́ \tau \rho ı \varsigma "$.

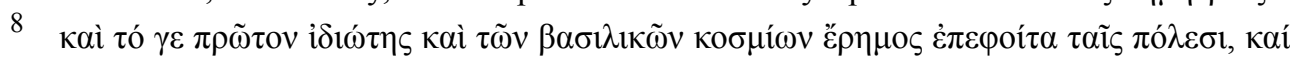

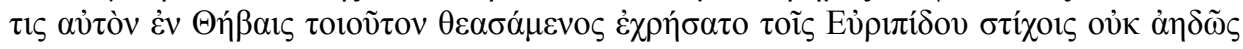
(Eur., Bacch. 4-5).

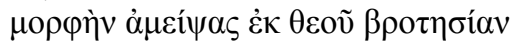

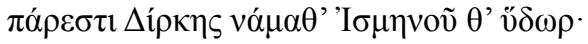


III. With these distinctions and mixings between the comic and the tragic halves in mind, let us now turn to the figures of Antigonus and Lamia. Both Antigonus and Lamia are prominent in the comic half of the Life, but Lamia is no longer mentioned after the mid-point switch, and Antigonus dies at the Battle of Ipsus, the first major episode of the tragic half. Let us begin with Lamia. Having won Lamia as booty from the victory at Cyprian Salamis, soon Demetrius the conqueror became the conquered as the "more experienced" Lamia used her charms to win him over (16.3-4). Demetrius' utter devotion to Lamia, and his philandering ways more generally, are the primary sources of humor in the comic half of the Life. Demetrius' dalliances include living in the opisthodomos of the Parthenon with a bevy of prostitutes; and levying a tax so that Lamia and her girls could pay for their cosmetics $(23.3 ; 27.1)$. Lysimachus had his own choice words concerning Lamia 25.6):

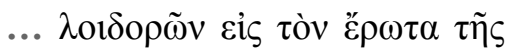

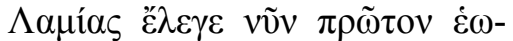

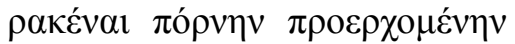

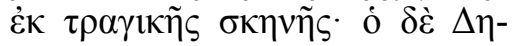

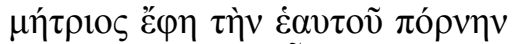

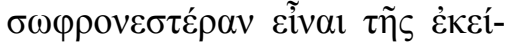

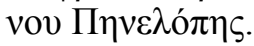

Once, mocking the man's passion for Lamia, he said that this was the first time he had ever seen a hooker coming forward to play a great tragic part; Demetrius, however, declared that his own hooker was more chaste than the Penelope of Lysimachus.

The humor of Lysimachus' comment relies on the incongruity between Lamia's naturally low status as a prostitute (note the use of porne and not hetaera) and her artificially lofty position as a de facto queen; Demetrius did not deny that fact in his retort, he merely argued that Lysimachus' situation is equally ridiculous because his purportedly noble queen is less modest than a whore. This incongruity can also be described as an unseemly mixing-up of the registers of comedy and tragedy, similar to the scenes of Demetrius' costume-changes, where low and high characters are playing the wrong parts in the wrong settings. Plutarch uses this tension throughout the Life to capture the mixed nature of Demetrius' character, always vacillating between his "great vices and great virtues."

A passage from the Moralia elucidates what lesson Plutarch is trying to teach his reader by incorporating a character like Lamia in the Life of Demetrius. In his Comparison of Aristophanes and Menander, Plutarch employs a similar female character to describe the comedy of Aristophanes (854A):

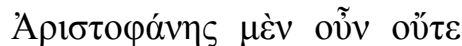

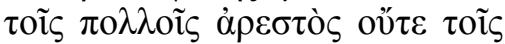

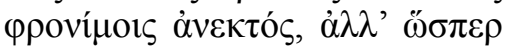

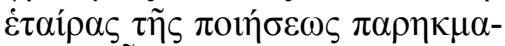

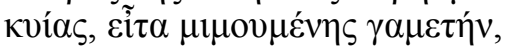

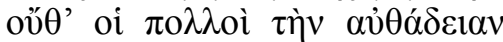




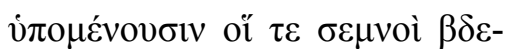

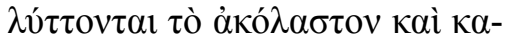
кół $\theta \varepsilon \varsigma$.

Now Aristophanes is neither pleasing to the many nor endurable to the thoughtful, but his poetry is like a courtesan who has passed her prime and then takes up the role of a wife, whose presumption the many cannot endure and whose licentiousness and malice the dignified abhor.

Though Lamia is not named explicitly, Plutarch clearly had the same sort of grotesquely debauched and inappropriately demanding woman in mind when he was writing the Life of Demetrius; the Moralia passage brings into high relief the fact that women like Lamia were subject to ridicule because they can be harmful to the public and offensive to the sensibilities of virtuous men. Furthermore, Demetrius is made ridiculous by his uxorious devotion to such a vicious woman, and for this he is mocked both publicly and privately. His ambassadors to Lysimachus jokingly compared their king's lovebites with the Lysimachus' scars from a lion's claws (27.3), and the courtesan Demo mocked Demetrius to his face for his unseemly love of a much older woman (27.4). Each time Plutarch's reader laughs at Lamia or, more likely, at Demetrius because of Lamia, the lesson that such debased actions or habits are contrary to a virtuous life is subtly yet powerfully reinforced.
Unlike Lamia, Antigonus is never the butt of the joke, but always the jester. Plutarch presents Antigonus' mode of communication as the clever quip, which he freely fired off to ambassadors, his companions, and especially his son. Nevertheless, Plutarch holds up the exceptional ease of their father-son relationship as a model for how kings and their sons should interact (3.2-3). Most of Antigonus' jokes about Demetrius make light of his son's profligate lifestyle, which gave Antigonus no concern because of his ability to succeed during campaigns. One favorite example of Antigonus' wit will suffice (19.5):

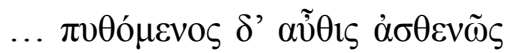

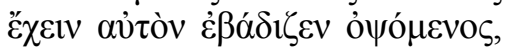

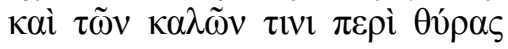

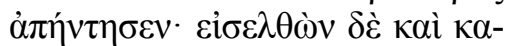

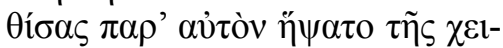

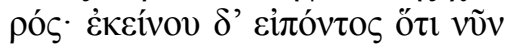

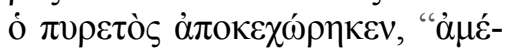

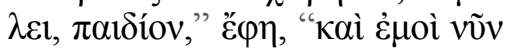

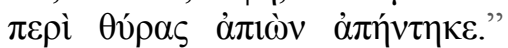

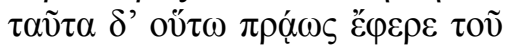

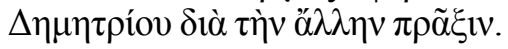

...And again, learning that his son was sick, Antigonus was going to see him, and met a certain beauty at his door; going in, he sat down by his son and felt his pulse. "The fever has left me now," said Demetrius. "No doubt, my boy," said Antigonus, "I met it just now at the door as it was leaving." He bore Demetrius' trifles so lightly on account of his other actions. 
His wit focused specifically on Demetrius' personal vices, whereas he found nothing ridiculous about Demetrius' generalship; indeed, Plutarch characterizes Antigonus as "not weighed down by his son's luxuries, extravagances, and drinking" (19.3, $\tau \rho v-$

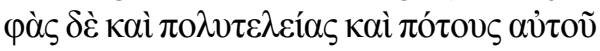

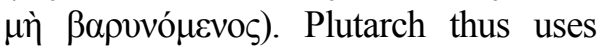
Antigonus' wit and indulgence to instruct his readers how to distinguish between the vices and virtues of Demetrius' great nature. In many ways, Antigonus resembles Micion, the indulgent father of Terence's Adelphoe, who believes that leniency is the best policy in childrearing ${ }^{9}$. I would not suggest any kind of specific intertextual allusion on Plutarch's part (although it is not out of the question), but rather I propose that Plutarch was utilizing a stock character familiar from New Comedy in his construction of Antigonus.

The image of Antigonus as the jovial and indulgent father disappears as soon as the narrative's tone transforms from comic to tragic. Plutarch now foregrounds the negative aspects of Antigonus' character, who is "by nature stern and haughty, and was harsh in what he said no less than in what he did"

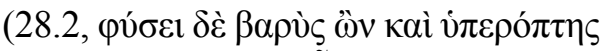

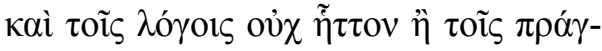
$\mu \alpha \sigma i \tau \rho \alpha \chi v()$ ). When Antigonus saw that he was at a disadvantage against the enemies united against him at Ipsus, his countenance completely changed, and his previous sense of humor was noticeably missing; his casual pre-battle jokes were now replaced by silence and introversion (28.4). Plutarch draws our attention to a lack of humor as the most prominent sign of Antigonus' realization of his impending defeat, and by draining the humor out of the narrative's most vocal jester, it underscores Plutarch's claim that the narrative of Demetrius' life has moved from the comic to the tragic stage. Plutarch does record one quip of Antigonus at this point in the narrative (28.5):

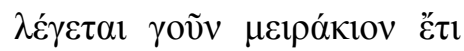

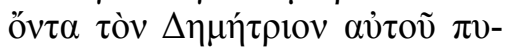

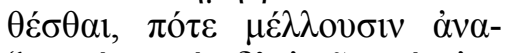

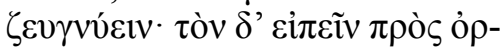

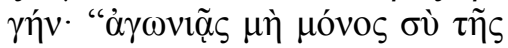

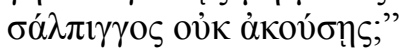

At any rate, it is said that Demetrius, while still a young man, asked his father when they were going to break camp; and that Antigonus answered in anger, "Are you worried that you alone will not hear the trumpet?"

It is an angry rebuke instead of a light wisecrack, but it still has a kernel of humor: it is laughable to think that of all men, the general's own son would miss the alarm. Furthermore, Plutarch breaks from the chronology of the narrative in order to include this anecdote at this point. If he had placed

See in particular Ter., Adelphoe 26-81. 
this story in the chronologically-appropriate moment of the narrative, it would have confused the initial characterization of Antigonus as indulgent, light-hearted father; placed where it now stands, the potentially humorous story instead highlights Antigonus' sharp temper and tongue within the boundaries of the tragic half.

IV. To sum up thus far: the humor associated with Antigonus and Lamia in the comic half of the Life is light-hearted in tone, but nevertheless contains a serious lesson about the characteristics and habits the virtuous reader of Plutarch should avoid. Demetrius' vices are treated as follies, but the very fact that humor and laughter are directed at them serves to distinguish these vices from Demetrius' virtues. In the tragic half, Plutarch does not remove humor altogether, but rather adapts its use to fit the more serious narrative of Demetrius' fall from power. The predominant type of humor which the reader encounters during the narrative of Demetrius' demise is gallows-humor, the tense sort of laughter which arises when one is face-to-face with death. In general, these passages serve to undermine Demetrius' inflated self-perception, and to emphasize the negative consequences of his character-flaws which were underplayed in the comic half.

A few examples demonstrate the grotesque humor with which Plutarch peppers the narrative. First, Plutarch recounts two tales from the Athenian famine which occurred when Demetrius cut off the city's grain supply (34.2):

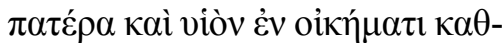

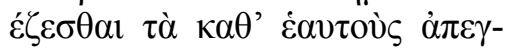

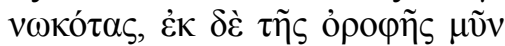

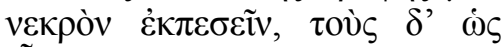

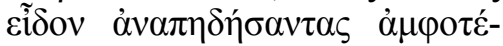

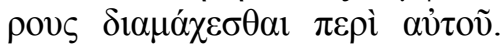

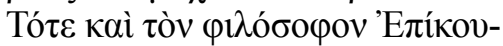

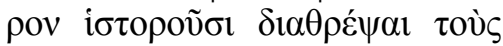

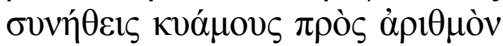
$\mu \varepsilon \tau^{\prime} \alpha \nu \jmath \tau \tilde{\omega} v \delta 1 \alpha v \varepsilon \mu o ́ \mu \varepsilon v o v$.

A father and a son were sitting in a room and had abandoned all hope. Then a dead mouse fell from the ceiling, and the two, when they saw it, sprang up and fought with one another for it. Also at this time, they say that the philosopher Epicurus sustained the lives of his associates with beans which he counted out and distributed among them.

Out of context, the images of father and son fighting over a dead mouse, or Epicurus rationing beans to his students are certainly entertaining; yet in the context of a famine, these humorous scenes enhance the horrors of starvation. A passage of similar dark humor comes during Demetrius' siege of Thebes, when his son Antigonus asked his father why they continued to waste lives unnecessarily; to which Demetrius angrily replied, "Why are you upset? Or do you owe rations to the dead?" (50.2). This angry retort both ridicules the younger Antigonus, while at the same 
time underlining the point he was making, i.e. Demetrius is utterly insensitive to the lives lost in his futile siege. Like father, like son: this exchange encourages the reader to recall Demetrius' relationship with his own father, the elder Antigonus, and the clever lines with which Antigonus was accustomed to chastise his son. In particular, this scene is reminiscent of the anecdote Plutarch recounts before the Battle of Ipsus (28.5, discussed in III above), in which Demetrius was rebuked for his anxiety that he would not hear the battle-cry. The sons in both passages demonstrated what are proper soldierly virtues, a concern for one's men and an eagerness for battle, yet in the mixed-up world of the Successors, these virtues are shot down by their stern, megalomaniacal fathers. As such, Plutarch uses Demetrius' witty quip in this passage to highlight his blind ambition and impending doom by connecting him to his father Antigonus, whose hubris led to his own devastation at Ipsus.

A final example of gallows-humor comes from Demetrius' march through Asia before his eventual capture by Seleucus. One of his soldiers, without rations but not without a sense of humor, posted in front of Demetrius' tent a riff on the opening lines of Sophocles' Oedipus at Colonus $(46.5)^{10}$ :

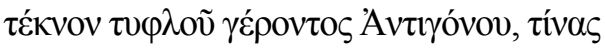

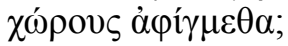

O child of blind and aged Antigonus, what are these regions to which we have come?

The wit of this clever allusion is dazzling, but yet again, it is an act of laughing in the face of death and mocking the mad ambition of Demetrius. In all of these examples, Plutarch uses the lightness associated with humor to draw attention to just how dark circumstances had become. Moreover, all of these examples illustrate the dire consequences of the sort of ambition which destroys everything in its path. Demetrius had no qualms about sacrificing the lives of Athenians or his own soldiers in his quest for power. These arresting moments of humor at points of deep tragedy would catch the attention of even Plutarch's most casual reader.

In the last passage we will consider, Plutarch ties together the themes of folly, entertainment, ambition, and morality with the end of Demetrius' life (52.1-3). In many ways, this penultimate chapter of the Life encapsulates the tensions between comedy and tragedy, the humorous and the serious, which we have seen at play so far. Demetrius was captured by Seleucus and for the last three years of his life, was put in a regal captivity in the Syrian Chersonese (50.5). Plutarch tells us that at first, Demetrius endured his situation "rather easily",

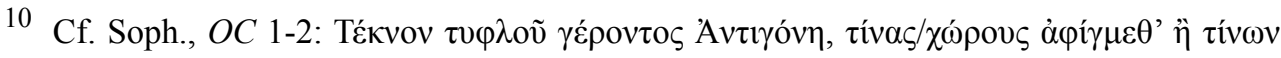
$\dot{\alpha} v \delta \rho \tilde{\omega} v \pi \tilde{\partial} \lambda \imath$; 
availing himself of opportunities to exercise by hunting, riding, or walking; he gradually bored of these pastimes, and turned to drinking and dice. Plutarch gives two possibilities for why Demetrius turned to such vicious hobbies: either he drank to escape from dwelling on his present captivity or because he had convinced himself that a life squandered fighting wars had only prevented him from attaining the life of idleness and leisure that he had always desired. The moment that Demetrius finally committed himself to living a wholly frivolous life is also the moment at which Plutarch abruptly breaks from the narrative and gives the reader the final lesson of the Life of Demetrius (52.3):

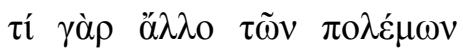

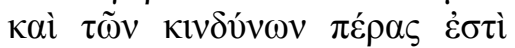

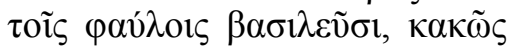

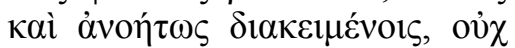

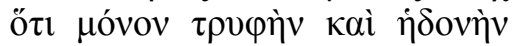

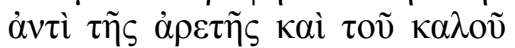

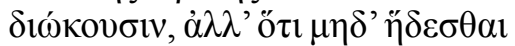

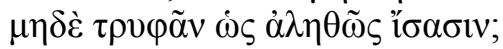

For what else is the goal of wars and perils for base kings, who are wickedly and foolishly disposed, not only because they pursue luxury and pleasure instead of virtue and what is noble, but also because they do not know how truly to enjoy pleasure or luxury?

This lesson is not conveyed through a funny quip or anecdote, or even a haunting piece of gallows-humor, but rather through a series of ironies. Demetrius realized too late that The Good of military conquest which he had always sought was no Good at all. Even in this self-realization, Plutarch shows that Demetrius was still wrong, because he chose to pursue pleasure and luxury instead of virtue. Moreover, base kings, that is, kings who not sophos, will always share this fate, because they do not know how to enjoy even the false Goods which they have chosen for themselves. Demetrius' misguided realization leads directly to his death, which Plutarch records as being caused by inactivity and overindulgence in food and wine. Through his drunkenness and gluttony, Demetrius is cast in the light of a comic character who slavishly serves his basest physical desires; at the same time, Plutarch reminds us that this man was a fallen king, though vicious and foolish, and his death in captivity is at least as tragic as is it comic.

V. During the course of this essay, I have demonstrated the wide variety of humor which Plutarch uses in just this single biography: one-liners, anecdotes, literary allusions, and irony. I maintain that Plutarch does not include humor haphazardly in the Life of Demetrius, but rather adapts its tone and function to fit within a framework of a comic half and a tragic half, where lighthearted humor is featured in the former and gallows-humor in the latter. Folly and dark humor work together to unite the disparate halves of the narrative, 
by consistently directing the reader's laughter and derision at Demetrius' vices and their consequences. Plutarch has followed through with his promise in the prologue, that he is including the Demetrius-Antony pair not merely for the sake of entertainment. Indeed, he has crafted the Life of Demetrius so that humor is used as a tool for moral education, not a distraction from it, and in the process has created a moral biography which could appeal to casual and ideal reader alike.

\section{BibliogRAPHY}

Duff, T.,

- "Plato, Tragedy and the Ideal Reader in Plutarch's Demetrios and Antony”,
Hermes 132 (2) (2004) 271-291.

Fowler, H. N.,

- Plutarch's Moralia, vol. X, London, 1936 (LCL).

LACY, P. DE,

- "Biography and Tragedy in Plutarch", AJPh, 73 (1952) 159-171.

Martin, R. H.,

- Terence: Adelphoe, Cambridge, 1976.

Mossman, J.,

- "Tragedy and Epic in Plutarch's Alexander", JHS, 108 (1988) 83-93.

Perrin, B.,

- Plutarch's Lives, vol. IX, ed., transl., London, 1920.

ZAdorojnyi, A.,

- "Tragedy and epic in Plutarch's Crassus", Hermes, 125 (2) (1997) 169-182. 